\title{
Exploring factors influencing voluntary turnover intent of Generation X public servants: A South African case
}

\author{
Hester Nienaber: University of South Africa \\ Vhusthilo Masibigiri: Equity Skills \& Talent Management Pty Ltd
}

Purpose: The purpose of this article is to report on the factors perceived to influence the turnover intent of Generation X public servants.

The problem: The researcher investigated the factors that Generation X public servants in South Africa perceive as influencing their turnover intent.

Design: The problem was studied by way of a case study. The data were collected by means of semistructured interviews. A total of eight purposively selected Generation X public servants participated in this study.

Findings: The findings of the study show that the factors influencing the turnover intent of the Generation X public servants correspond to some of those proposed in the literature, including the nature of the job, traditional attitudes, and organisational context, both on the macro- and the microlevels. Furthermore, these factors are also congruent with the drivers of engagement as set out in the literature, specifically content, coping, compensation, community and career. One of the implications of the findings of this study is that although the value of employees to organisations were established as long ago as the Renaissance, organisations still do not capitalise on their most important asset. It is in particular the direct (line) manager that plays a crucial role in optimising the value-add of employees.

Value: This study is original as it was the first to investigate the turnover intentions of Generation $X$ public servants. Generation X employees are important as they are deemed to be the knowledge repositories of organisations and they are next in line to support the organisation when the Baby Boomers retire. The perceived turnover intentions correspond to some of the components of the generic turnover model proposed by Holtom et al. (2008). The question that arises is whether the turnover intentions of Generation X are any different from other generations.

Conclusions: Given their unique characteristics, Generation $X$ is a turnover risk, which is facilitated by employee mobility. The line manager has control over all the components influencing turnover intent, while engagement is omnipresent in these components. It is the role and responsibility of the line manager to facilitate engaged employees, which would equate to affectively committed employees, by attending to these components. In so doing the line manager can prevent the costly implications of employee turnover while capitalising on their value to the organisation.

Key words: Turnover intent; Generation X; public servants; South Africa; commitment; engagement; drivers of engagement; line manager; competitive sustainability

\section{INTRODUCTION}

Employees' importance to the organisation has been acknowledged since the Renaissance (Owen, 1813, cited in Merrill, 1970), because of the central role they play in creating and sustaining competitive advantage (Barney \& Hesterly, 2011; Boxall, 1998; Carpenter \& Sanders, 2009; David, 2011; Grant, 2010). Competitive advantage is necessary to achieve high performance and to 'outwit' competition. Nowadays factors such as the changing world of work, technological advancement and globalisation seem to have heightened the importance of employees. These factors intensify competitive pressures on organisations. Since employees are at the forefront of business agendas to ensure the organisation's competitive sustainability, organisations pay increased attention to talent management in making certain that the right staff, at all hierarchical levels, is hired, developed and retained to ensure the organisation's ongoing competitive advantage (Cappelli, 2008; Cheese, Thomas \& Craig, 2008; Lewis \& Heckman, 2006). 
However, the real challenge for organisational leaders is to make sure that their talent is engaged (Cheese et al., 2008; Harvey, 2009; Linne, 2009) so that high performance can be achieved. According to Dyer (2009) an engaged employee is one who knows what his/her organisation does, can articulate its competitive advantage accurately and with passion, cares about its customers, and communicates with colleagues even in informal settings. This means that employees must be aligned with the strategy of the organisation and be motivated to achieve the goals of the organisation (Cheese et al., 2008). Furthermore, Cheese et al. (2008) draw attention to the fact that engagement can be identified in terms of physical, intellectual and emotional components. Research has also shown that leadership, and in particular that of the line manager, plays a crucial role in employee engagement, as a precursor to customer service, service quality, customer loyalty and staff retention (Cordeniz, 2002; Dewhurst, 2009; Dyer, 2009; Perrine, 2009). Furthermore, organisations that compete on service quality and customer loyalty may endeavour to keep staff turnover low as research has shown that service quality is higher where staff turnover is lower as a consequence of employee motivation (Schlesinger \& Heskett, 1991).

Having the right talent available may be a challenging task for contemporary organisations in view of the war for talent, skills shortages, employee mobility, the imminent retirement of the Baby Boomer generation and even the recent recessionary lay-offs. The availability of the right talent in the public sector may be an even greater challenge than in the private sector, as financial rewards are generally lower than in the private sector (Niewenhuizen, 2009). These phenomena adversely affect the ability of an organisation to create and maintain competitive advantage and consequently sustain their performance. Furthermore, retaining Generation $X$ may be challenging given their unique characteristics, especially their nomadic behaviour (Johnson, 2004; Perrine, 2009; Vaughn, 2008). They tend leave their jobs every $3^{1} \frac{1}{2}$ years (Cordeniz, 2002). Furthermore, their work ethic is characterised by a decline in trust and loyalty to the organisation (Holbeche, 2009). This is understandable, especially in view of contemporary organisational life being portrayed as 'dark and evil' (Kaiser \& Hogan, 2010). According to Kaiser and Hogan (2010) research has shown that managerial trustworthiness is important in organisational trust. It is particularly the degree to which employees trust their direct line manager that is correlated to job satisfaction, job performance and exercising discretionary effort. In the case of South Africa, the unavailability of skilled managers (Temkin, 2008, 2009) may exacerbate the situation. All of these variables are pertinent to employee turnover.

Employee turnover adversely affects organisations in a number of ways, all of which result in added competitive pressures. Since voluntary turnover is preventable, these additional competitive pressures can be avoided. According to the synthesis review by Holtom, Mitchell, Lee and Eberly (2008), employee turnover has been extensively researched mainly in the USA, Australia and the UK. However, turnover of Generation X public servants has not specifically received attention. This article fills a gap in the literature in that Generation $X$ is viewed as knowledge repositories of organisations. Moreover, from a financial perspective, turnover incurs costs, which are mostly hidden from (plain view of) managers (Holtom et al., 2008) as these costs are not identified, calculated and reported on. Alternative staffing costs are obvious, while the costs associated with the loss of knowledge, interruption in customer service and 'survivors' reaction to turnover' are not always visible or calculated (Kuean, Khin \& Kaur, 2010) and are thus often ignored or go unobserved. Consequently, it stands to reason that it is prudent for managers to avoid voluntary turnover, which is dysfunctional, as pointed out.

Given the importance of (engaged) employees in achieving high performance, the purpose of this article is to report on a study that, amongst others, explored factors that influenced the turnover intent of Generation X public servants in a South African context. If the reasons for turnover intent are known, organisations (specifically the public sector) can institute strategies to pro-actively prevent the turnover of Generation X employees. This article focuses on the factors perceived to influence the turnover intent of a specific cohort of Generation X public servants.

\section{LITERATURE REVIEW}

Literature on employee turnover as well as Generation $X$ was reviewed. The sections below report on employee turnover as well as turnover of public servants. Finally, a description is given of Generation $\mathrm{X}$. 


\section{Employee turnover}

Different types of staff turnover are described in the literature. Regardless of the type of turnover, all are generally associated with negative effects (costs and disruptions) on organisational performance. Voluntary turnover is described as the unplanned loss of workers, who leave on their own accord, and whom employers would prefer to keep (Frank, Finnegan \& Taylor, 2004). Voluntary turnover can be either avoidable or unavoidable. The former can be prevented as it involves change of job or early retirement; the latter, on the other hand, happens in unavoidable circumstances like the death of an employee (lqbal, 2010). The former type is the focus of this article, as factors that influence voluntary turnover are within the control of management (especially direct line managers) and can thus be prevented.

Voluntary staff turnover has been studied over a long period and from different viewpoints. The seminal work in this regard is deemed to be that of March and Simon (1958), who argue it is important to balance employee and organisation contributions and inducements to prevent employees from leaving. They maintain that two factors determine an employee's balance, namely (1) perceived desirability to leave (i.e. job satisfaction), and (2) perceived ease of leaving (i.e. alternatives). March and Simon (1958) maintain that a number of factors influence job satisfaction and perceived alternatives. The former is influenced by individual differences like personality and ability, while the latter is influenced by the nature of the job, such as scope, autonomy and role status, for example. Individual differences (also) influence the ease of movement, while the nature of the job influences job satisfaction, and thus the desirability of leaving. This exposition shows that factors influencing job satisfaction and perceived alternatives are intertwined.

Subsequent studies into voluntary employee turnover elaborated on the model proposed by March and Simon (1958) (for a comprehensive exegesis see Holtom et al., 2008). The variables proposed by March and Simon were expanded (Habib, Mukhtar \& Jamal, 2010; Olorunsola, 2010; Salarzehi \& Amiri, 2010; Soltani \& Liao, 2009) and some variables were added to the voluntary turnover model proposed by March and Simon (1958), giving a more complete understanding of this phenomenon. These variables include attitudes (Allen \& Myer, 1996; Cavanaugh, Boswell, Roehling \& Boudreau, 2000; Habib et al., 2010; Jackson, Schwab \& Schuler, 1986; Kuean et al., 2010; Meyer, Stanley, Herscovitsch \& Topolnytsky, 2002; Pepe, 2010; Podsakoff, LePine \& LePine, 2007; Porter \& Steers, 1973; Rekha \& Kamalanabhan, 2010; SamGnanakkan, 2010; Singh \& Loncar, 2010; Yin-Fah, Foon, Chee-Leong \& Osman, 2010), contextual factors (Dawley, Houghton \& Buckley, 2010; Price, 1977; Wheeler, Harris \& Harvey, 2010) on both the macro- (Graen, Liden \& Hoel, 1982; Haywood, 2011; Habib et al., 2010; Pfeffer \& Davis-Blake, 1992; SamGnanakkan, 2010; Shahzad, Hussain, Bashir, Chishti \& Nasir, 2011; Rekha \& Kamalanabhan, 2010 Singh \& Loncar, 2010) and micro-levels (Colquitt, Conlon, Wesson, Porter \& Ng, 2001; Fulford, 2005; Lee, Chen, Wang \& Dadura, 2010; Salarzehi \& Amiri, 2010; Soltani \& Liao, 2009; Tekleab, Takeuchi \& Taylor, 2005) and decision alternatives (Hom, Griffeth \& Sellaro, 1985; Lee \& Mitchell, 1994).

Further studies shed light on withdrawal behaviours preceding voluntary turnover. These behaviours include withdrawal cognitions, job search behaviours and withdrawal behaviours, all of which contribute to the ultimate decision to remain with or leave the organisation. The foregoing factors can be considered moderators of turnover. More importantly, the work of Price and Mueller $(1981,1986)$ concluded that job satisfaction and the intent to leave are mediated by organisational commitment. Organisational commitment is defined as a psychological link between an employee and his/her organisation that makes it less likely for the employee to leave the organisation voluntarily (Allen \& Meyer, 1996). According to Allen and Meyer (1996) organisational commitment can take three distinct forms:

- Affective commitment means that the employee identifies with the organisation, is involved in the organisation and is emotionally attached to the organisation. Employees with a strong affective commitment remain with the organisation because they want to do so.

- Normative commitment refers to commitment based on a sense of obligation to the organisation. Employees experiencing normative commitment remain with the organisation because they feel they ought to do so.

- Continuance commitment indicates a situation where an employee is aware of the cost of leaving the current employer. Employees with a continuance commitment remain with the organisation because they have no choice. 
The variables influencing turnover intent are shown in Figure 1. However, different authors grouped these variables differently (see for example Kuean et al., 2010; lqbal, 2010; Shahzad et al., 2011). Nevertheless, the basic tenants of the model of March and Simon (1958) have remained.

This exposition of voluntary employee turnover shows that this phenomenon is influenced by multifaceted factors, which are interlinked in some cases, denoting the complex nature of turnover. As such, the model of Holtom et al. (2008) captures these variables as illustrated in Figure 1 below.

Figure 1: Turnover model proposed by Holtom et al. 2008

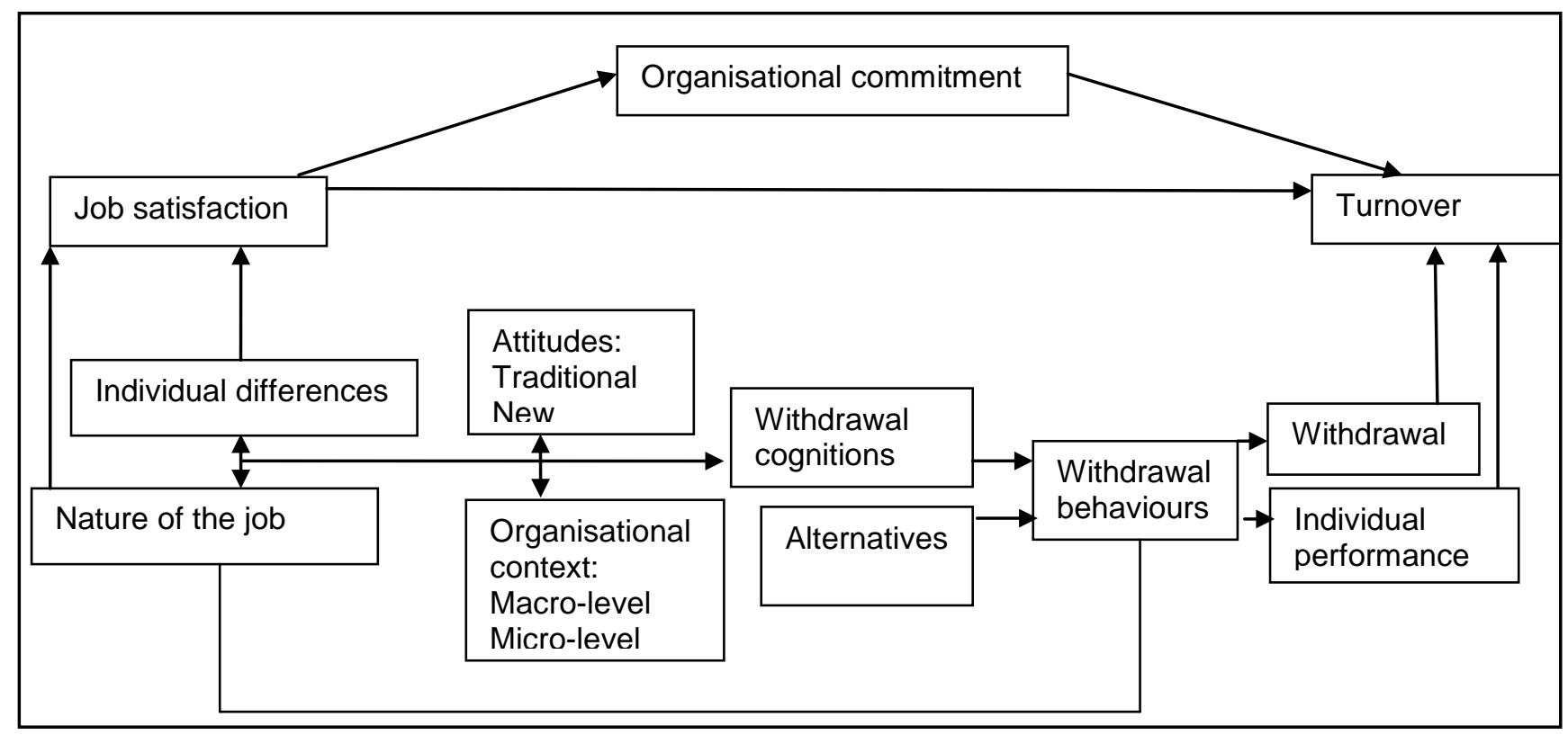

Source: Adapted from Holtom et al. 2008:244

From Figure 1 it appears as if the role of engagement was overlooked in the turnover research. However, a close scrutiny of the literature on engagement (especially the work of Cheese et al., 2008) shows that engagement is implicitly intertwined throughout the turnover model proposed by Holtom et al. (2008). Cheese et al. (2008) explain what the drivers of engagement are. These drivers can be linked to the components of the turnover model of Holtom et al. (2008) in the following ways:

- Content refers to the actual content of the work, which ranges from the physical and emotional demands that the job makes on the employee, the sense of achievement that the job offers, the opportunity to learn or discover new things, and whether it is meaningful and leads to some form of satisfaction. Content corresponds to a greater or lesser degree with the nature of the job, and to traditional and newer attitudes as illustrated in the model in Figure 1.

- Coping indicates whether the employee has been given the means to handle the job and whether his/her goals are achievable. Coping involves knowledge, skills, technology and training as well as a favourable working environment, supportive managers and colleagues and work practices and processes that reduce effort rather than adding to it. As such, coping is (partly) represented by individual differences, newer attitudes, and organisational context on the macro- and micro-levels, as illustrated in Figure 1.

- Compensation refers to the employee's notion of being fairly financially rewarded as well as being recognised for his/her contribution. In the main, compensation is rather a feeling that the employee is fairly rewarded for his/her contribution, the evaluation of which is understood by the employee and experienced as fair, which is reasonably market related, signalling recognition. Consequently, compensation corresponds to organisational context on the macro- and microlevels, as illustrated in Figure 1.

- Community refers to a feeling of positive social interactions in the workplace, as well as whether the work is deemed to be fulfilling, meaningful work, enjoyable, fun and done in a supportive or collaborative rather than a confrontational environment. This driver of engagement is interwoven with the nature of the job as well as with organisational context on both the macro- and microlevels, as shown in Figure 1. 
- $\quad$ Congruence refers to the agreement between the individual and organisational values and alignment of expectations and includes met values. As such congruence corresponds to organisational context on the macro- and micro-levels as well as traditional attitudes, as reflected in Figure 1.

- $\quad$ Career denotes the alignment between the career and life expectations and aspirations of the individual over both the short and the long term, including work-life balance, whether the organisation is investing in them and whether employees can shape their own destiny. Career corresponds to nature of the job and traditional attitudes, as shown in Figure 1.

Cheese et al. (2008) argue that an engaged employee is a deeply committed employee. However, in view of the above, it appears that an engaged employee is committed at the affective level - i.e. the employee is with the organisation because he/she wants to be there. Cheese et al. (2008) point out that engaged employees are less likely to leave the organisation and more likely to spend their career with the organisation.

The role of the line manager in creating conditions that encourage employee engagement cannot be overemphasised (Cheese et al. 2008), especially in the case of Generation X employees (Ahlrichs, 2007; Cordeniz, 2002; Dewhurst, 2009, Dyer, 2009, Graen et al., 1982, Johnson, 2002; Kaiser \& Hogan, 2010; Perrine, 2009; Pfau \& Kay, 2002; Rodriguez, Green \& Ree, 2003; Rose \& Gordon, 2010; Salopek, 2008; Wheeler et al., 2010). According to these authors factors influencing engagement include trust and integrity of leadership/the line manager, nature of the job, ability to align individual effort with organisational performance, career growth opportunities, pride in the organisation, relationships with co-workers, personal development and the relationship with the immediate manager. All of these are intertwined with the factors influencing turnover, as presented in Figure 1. It should, however, be noted that none of these studies differentiate between variables affecting the turnover intent of the different generations, including Generation X.

\section{Turnover of public servants}

No studies are available on the turnover intent of Generation X public servants specifically, though a few studies pertaining to turnover of public servants concluded the following:

Salarzehi and Amiri (2010) found that job factors like the administration process, team working (interpersonal relationships) and desirable working conditions - both physical and mental, - were the most important in nurses' turnover in a state-owned hospital in Iran. These factors are followed by organisational factors (salary, promotions and organisation policies) and then individual factors (characteristics and personality). According to the Holtom et al. (2008) model these factors can be classified as the nature of the job, traditional attitudes and organisational context on both macro- and micro-levels. In terms of the drivers of engagement (according to Cheese et al., 2008) these factors can be categorised as content, coping, compensation, community and career.

Shahzad et al.'s (2011) study of employee turnover in the public sector of Pakistan found that employees who are dissatisfied with career growth opportunities and the organisational environment (physical as well as meaningless work coupled with strenuous rules and regulations and poor relationships with especially management) tended to leave the organisation. In this instance, the categories nature of the job, attitudes and organisational context of the Holtom et al. (2008) model are applicable. In the case of the Cheese et al. (2008) model, content, career and community are relevant.

Singh and Loncar (2010) found that in the case of unionised nurses, job satisfaction had a more crucial impact on turnover intent than pay satisfaction. In this instance, traditional values of the Holtom et al. (2008) model and content of the Cheese et al. (2008) model are pertinent.

The turnover intent studies carried out at public sector institutions indicated that the turnover intent of public servants can be classified into the model proposed by Holtom et al. (2008). All of the components are relevant to a greater or lesser degree, especially the nature of the job, attitudes and organisational context on both the macro- and micro-levels. These are also consistent with the drivers of engagement as identified by Cheese et al. (2008), in particular content, coping, community, compensation and career. However, no turnover study was specifically done with Generation X as target audience. The next section describes Generation X. 


\section{Generation X}

The unique characteristics of Generation $X$, and their different set of goals, aspirations and values (Ahlrichs, 2007; DeMarco, n.d.; Johnson, 2004; Western \& Yamamura, 2006), make them a turnover risk. There is no consensus in the literature about the date range that defines Generation X. For the purposes of this study Generation Xers were deemed to have been born between 1965 and 1981 (Bova \& Kroth, 2001), as 1965 is the most often-quoted starting date and 1981 a frequent ending date. The literature is consistent in characterising Generation X. This generation often grew up alone, as their parents were working and many of their parents were divorced (Cordeniz, 2002). Hence, Generation Xers are concerned about life balance and they are protective of the family (DeMarco, n.d.). Furthermore, they tend to be sceptical and pragmatic and value leadership by competence (Cordeniz, 2002). Generation Xers prefer leadership behaviours that are associated with generational themes, especially flexibility, recognition and challenging working conditions where they can use their skills (Cordeniz, 2002; Perrine, 2009; Pfau \& Kay, 2002; Rodriguez et al., 2003; Salopek, 2008). Human resource $(\mathrm{HR})$ practices valued by Generation $X$ employees include flexible working arrangements in terms of working time, work and rewards (Cordeniz, 2002; Johnson, 2002; Rose \& Gordon, 2010), recognition, including equitable pay (Ahlrichs, 2007; Perrine, 2009), training (including mentoring) and development, given that they are loyal to their skills (Ahlrichs, 2007; Cordeniz, 2002; Rose \& Gordon, 2010; Ruch, 2000; Vaughn, 2008) and performance management (including feedback) (Rose \& Gordon, 2010; Salopek, 2008; Schachter, 2009; Taylor, 2002; Vaughn, 2008). Generation Xers have no respect for service, title or rank, because their parents had it all but lost their jobs in any event (DeMarco, n.d.). Generation Xers are independent and have a desire for belonging and meaningfulness of work (Perrine, 2009; Vaughn, 2008). However, they regard life experiences as being more important than work (Johnson, 2004). They tend to be loyal to their skills rather than to an employer, hence they have no objection to crossing borders to augment and hone their skills (Ruch, 2000), which makes it difficult to retain this generation (Johnson, 2004). Generation Xers value communication, as this facilitates participation in true exchange of ideas, and ensures that messages are heard and understood (Perrine, 2009; Schachter, 2009; Vaughn, 2008). Furthermore, communication is deemed to ensure career development (Pfau \& Kay, 2002), which is critical for Generation $\mathrm{X}$ employees to feel they are contributing and trusted with some control over their work (Ruch, 2000). These unique characteristics of Generation Xers tie in with factors influencing turnover, as set out in the previous section.

Given the above exposition of Generation $\mathrm{X}$ it is clear that all of the components of the turnover model of Figure 1 are applicable to Generation $X$ employees. Furthermore, the drivers of engagement as proposed by Cheese et al. (2008) are equally applicable.

\section{METHOD}

The inquiry reported on in this article was situated in an interpretivist research philosophy (Maree, 2007), with its emphasis on experience and interpretation, of Generation X public servants as to the factors influencing their turnover intent. This research philosophy is congruent with the purpose of this research as it set out to explore Generation X public sector employees' perceptions of factors influencing their turnover intent with a view to understanding this phenomenon. The descriptions of the participants' perspectives of the social reality studied provided data which formed the basis of themes and categories regarding the perceptions of factors influencing their turnover intent. These factors could be used to develop strategies preventing Generation X public servants' intent with regard to turnover. The above explanation of the interpretivist philosophy alludes to the application of a qualitative research approach in collecting and analysing data for this research. This approach is in line with the predominant research approach within the interpretivist philosophy as explained by Collis and Hussey (2009), Creswell (2009), Hallebone and Priest (2009), Henning, Van Rensburg and Smit (2004) and Maree (2007).

The problem was studied by way of using multiple case studies as this approach made it possible to explore this phenomenon in its real-life context (Meyers, 2009; Perry, 2001). Ten participants, complying with the criteria of being a Generation X, as per Bova and Kroth (2001) and a public servant, were purposively selected. Eight of these potential participants were eventually interviewed. Each interview lasted for an hour, at a place convenient to the interviewee. There is no ideal sample size for qualitative studies, but the number of participants in this case is in keeping with the guidelines set for both case studies and interviews. Eisenhardt (1989) proposes between four and 10 for cases, while Morse (1994) suggests six cases and Creswell (2002) three to five cases. Guest, Bunce and 
Johnson (2006) suggest that between six and 12 interviews should suffice. The small sample is also congruent with the interpretivist research philosophy as put forward by Saunders, Lewis and Thornhill (2009) as is the data collection technique of interviewing. Furthermore, Morse (1994) also suggests an alternative to sample size, namely "saturation". Guest et al. (2006) maintain that saturation, the point at which no new information or themes are added, especially at a meta-theme level, can occur as early as six interviews. The unit of analysis was the individual Generation X participant interviews at the theme level (Babbie, 2007; Perry, 2001; Prasad, 2008).

A realist approach, as described by Fisher (2010), was adopted. According to the realist style, concepts exist independently of how people perceive or experience reality. Furthermore, the concepts are cognitively accessible to those observing it. Nevertheless, 'accessible' does not mean knowledge is a perfect interpretation of reality, but approximately objective. As such, people can know about the concepts relatively objectively (Fisher, 2010).

An interview guide consisting of 15 open-ended questions was used to obtain information for the entire study, which included factors influencing both retention and turnover of Generation X public servants. These 15 questions were divided into three categories - one each covering demographics (i.e. race, gender, salary, educational qualification, home language, marital status), factors influencing retention (factors that will ensure that the participant remains with the employer, if the respondent was the manager what he/she should have done to retain staff, feelings about compensation, coping, community, work-life-balance) and factors influencing turnover (behaviour like absence from work, feelings about present job, if unhappy, what are the reasons causing this feeling of the participant, if unhappy, when the unhappiness will pass, main reasons why others leave the organisation and reasons why the participant would leave the organisation).

The researcher complied with rigorous standards of research, namely ensuring that suitable, cooperative participants participated, without whom valid conclusions are not possible (Baruch \& Holtom, 2009). Since this research posed minimal risk to participants and the information provided during the interview was not of a sensitive nature, it suffices to report on informed consent, which reflects autonomy or respect for persons, which is one of the principles of research ethics (Pace \& Livingston, 2005). Informed consent acknowledges that persons should be treated as autonomous agents and that persons with a diminished ability are entitled to protection. At the same time informed consent pays attention to voluntary participation and reasonable protection of the person's privacy; explains the purpose of the study, making sure that the explanation provided was understood, including possible risks and benefits to potential participants; the voluntary permission of the participants to participate in the study and the participants ability to consent to the study (Holmes, 2009). This study complied with ethical considerations as informed consent was obtained from participants. They were assured that the information submitted would be treated as confidential and anonymous. They were not identified by name, but were numbered from one to eight, thus ensuring their reasonable protection. Reasonable protection was further ensured by storing the field notes, numbered from one to eight, in a filing cabinet. Permission was also obtained from the department in question to do the study. Furthermore, the participants were informed that their participation was voluntary and that they could withdraw at any stage if they so wished. Two of the 10 participants decided to withdraw after the purpose of the study was explained to them. By respecting their decisions to withdraw the researcher adhered to the principles of beneficence and justice.

The main limitation of this study was that the results cannot be generalised beyond the scope of the study, given the nature of this research design. Trustworthiness was ensured by using a formalised, structured process. The clarification of concepts, during the interview, took care of enhanced credibility, as both interviewer and interviewee could agree or disagree on the definition of the construct studied (Perry, 2001). The interviews were recorded by way of verbatim notes taken by the interviewer. Understanding was checked (Saunders, Lewis \& Thornhill, 2009:334) with interviewees during the interview as well as afterwards to ensure alignment with what interviewees had meant. It needs to be pointed out that although the interviewer was inexperienced, she ensured a productive interview by identifying questions relating to the problem studied in advance to make sure that all questions were answered by all interviewees. The interviews were recorded by way of painstaking, verbatim, note-taking, while responses were checked for understanding. In retrospect, it might have been beneficial to have recorded the interviews in addition to taking notes. Note-taking alone, instead of supplementing it with an additional aid like a tape- or video-recording, is considered to be a limitation of this study. 
The interview notes were analysed by applying content analysis, a research tool used to determine the presence of certain words or concepts within texts, in this instance interviews. According to Berelson (1952) content analysis is a research technique for the objective, systematic, and quantitative description of the manifest content of communication, all which are characteristics of the scientific method. "Objective" means that the results depend upon the procedure and not the analyst and is achieved by having the categories of analysis defined in a way that different persons can apply them to the same content and get the same results. In this instance the components of the Holtom et al. (2008) model of turnover as well as the drivers of engagement proposed by Cheese et al. (2008) were used. In addition, provision was made for a category "other" as the turnover intentions of Generation X public servants were not studied previously and as such different factors might have emerged and as such catered for in a category "other". "Objective" also means that the analyses are designed to secure data relevant to a research question (Prasad, 2008); in this instance the perceived turnover intentions of Generation X public servants. "Systematic" refers to the application of a set procedure to all the content ensuring that all relevant content is being analysed, resulting in the consistent inclusion or exclusion of content, irrespective of the researchers' ideas. "Quantitative" means the recording of the frequencies with which the various defined types of themes/content occurred. The importance of themes was established by means of identifying recurring mentioning (Berelson, 1952; Fisher, 2010). "Manifest content" refers to the apparent content, which means that content must be coded as it appears in the text, rather than as the content analyst feels it is intended. In adhering to the objective, systematic, and quantitative description of the manifest content of communication, content analysis ensures making valid, replicable and objective inferences about the message on the basis of explicit rules (Prasad, 2008). In addition to conceptual analysis, relational analysis was also applied. Relational analysis goes a step further than conceptual analysis by examining the relationships among concepts identified in a text. Individual concepts, in and of themselves, are viewed as having no inherent meaning. Rather, meaning and significance, is a product of the connections to other concepts in the text, in this case the interviews (Prasad, 2008).

The researchers analysed and quantified the presence, meanings and relationships of such words and concepts, then made inferences about the messages within the texts.

As the number of responses was small, data analysis was done manually by linking the themes to turnover factors in the literature. Furthermore, latent content could also be considered, as the exercise was done manually. The risk of losing meaning was countered by allowing for exhaustive categories dealing with similar meanings related to the purpose of the study and within the context of the study. In so doing, an attempt was made neither to omit or exclude relevant data nor to include irrelevant data. In this way the researcher endeavoured to ensure rigour. Rigour was maintained by using semistructured interviews, while the interview guide was pre-tested with a Generation X public servant who was not a participant in the study reported on.

\section{FINDINGS}

Eight of the 10 participants who were approached to participate in this inquiry accepted the invitation. They were all Generation Xers as per the definition of Bova and Kroth (2001), as all were aged between 27 and 43 at the time of the study - i.e. born between 1965 and 1981. Furthermore, they were all employed by various South African government departments and thus were public servants. Their responses can therefore be accepted as being relevant to this generation and employment sector. For ethical reasons, neither the names of participants nor government departments are identified in this article.

The next section provides a profile of the participants, which is followed by factors influencing their turnover intent.

\section{Profile of participants}

A profile of each of the participants, based on the characteristics of the participants, is provided in Table 1 below. 
Table 1: Profile of participants

\begin{tabular}{|c|c|c|c|c|c|c|c|c|}
\hline $\begin{array}{l}\text { Participant } \\
\text { characteristi } \\
\text { cs }\end{array}$ & 1 & 2 & 3 & 4 & 5 & 6 & 7 & 8 \\
\hline Language & Tswana & English & Venda & Venda & Venda & Venda & Venda & Venda \\
\hline Ethnic group & Tswana & Indian & Venda & Venda & Venda & Venda & Venda & Venda \\
\hline Gender & Female & Female & Male & Male & Male & Male & Male & Male \\
\hline $\begin{array}{l}\text { Marital } \\
\text { status }\end{array}$ & $\begin{array}{l}\text { Single } \\
\text { parent }\end{array}$ & $\begin{array}{l}\text { Single } \\
\text { parent }\end{array}$ & $\begin{array}{l}\text { Single } \\
\text { parent }\end{array}$ & $\begin{array}{l}\text { Single } \\
\text { parent }\end{array}$ & $\begin{array}{l}\text { Single } \\
\text { parent }\end{array}$ & $\begin{array}{l}\text { Single } \\
\text { parent }\end{array}$ & $\begin{array}{l}\text { Single } \\
\text { parent }\end{array}$ & $\begin{array}{l}\text { Single } \\
\text { parent }\end{array}$ \\
\hline $\begin{array}{l}\text { Salary per } \\
\text { annum }\end{array}$ & $\begin{array}{l}\mathrm{R} 150000 \\
- \\
\mathrm{R} 250000\end{array}$ & $\begin{array}{l}\text { R251000 } \\
- \\
\text { R350 000 }\end{array}$ & $\begin{array}{l}<R 150 \\
000\end{array}$ & $\begin{array}{l}<R 150 \\
000\end{array}$ & $\begin{array}{l}<\mathrm{R} 150 \\
000\end{array}$ & $\begin{array}{l}<R 150 \\
000\end{array}$ & $\begin{array}{l}<R 150 \\
000\end{array}$ & $\begin{array}{l}\text { R250 000- } \\
\text { R350 } 000\end{array}$ \\
\hline $\begin{array}{l}\text { Qualification } \\
\text { s }\end{array}$ & Honours & $\begin{array}{l}\text { Honours } \\
\text { degree }\end{array}$ & $\begin{array}{l}\text { Honours } \\
\text { degree }\end{array}$ & $\begin{array}{l}\text { Honours } \\
\text { degree }\end{array}$ & $\begin{array}{l}\text { First } \\
\text { degree }\end{array}$ & $\begin{array}{l}\text { Honours } \\
\text { degree }\end{array}$ & $\begin{array}{l}\text { Technical } \\
\text { qualificatio } \\
n\end{array}$ & $\begin{array}{l}\text { First } \\
\text { degree }\end{array}$ \\
\hline $\begin{array}{l}\text { Employment } \\
\text { capacity }\end{array}$ & $\begin{array}{l}\text { Profession } \\
\text { al }\end{array}$ & $\begin{array}{l}\text { Profession } \\
\text { al }\end{array}$ & $\begin{array}{l}\text { Profession } \\
\text { al }\end{array}$ & $\begin{array}{l}\text { Technic } \\
\text { al } \\
\text { staff }\end{array}$ & $\begin{array}{l}\text { Profession } \\
\text { al }\end{array}$ & $\begin{array}{l}\text { Profession } \\
\text { al }\end{array}$ & $\begin{array}{l}\text { Profession } \\
\text { al }\end{array}$ & $\begin{array}{l}\text { Profession } \\
\text { al }\end{array}$ \\
\hline $\begin{array}{l}\text { Number of } \\
\text { previous } \\
\text { employers }\end{array}$ & $4-5$ & $4-5$ & $4-5$ & 1 & $2-3$ & 1 & $4-5$ & 10 \\
\hline $\begin{array}{l}\text { Years with } \\
\text { current } \\
\text { employer }\end{array}$ & $4-5$ years & $5-6$ years & 5-6 years & $2-3$ & $<1$ & $1-2$ & $1-2$ & $7-8$ \\
\hline $\begin{array}{l}\text { Training } \\
\text { Self initiated } \\
\text { Employer- } \\
\text { initiated }\end{array}$ & $\begin{array}{l}1 \\
0\end{array}$ & $\begin{array}{l}3 \\
3\end{array}$ & $\begin{array}{l}3 \\
3\end{array}$ & $\begin{array}{l}1 \\
1\end{array}$ & $\begin{array}{l}1 \\
3\end{array}$ & $\begin{array}{l}0 \\
3\end{array}$ & $\begin{array}{l}3 \\
3\end{array}$ & $\begin{array}{l}3 \\
0\end{array}$ \\
\hline $\begin{array}{l}\text { Absence } \\
\text { Sick leave } \\
\text { Other leave }\end{array}$ & $\begin{array}{l}5 \text { days } \\
25 \text { days }\end{array}$ & $\begin{array}{l}50 \\
10\end{array}$ & $\begin{array}{l}2 \\
15\end{array}$ & $\begin{array}{l}0 \\
0\end{array}$ & $\begin{array}{l}12 \\
0\end{array}$ & $\begin{array}{l}5 \\
11\end{array}$ & $\begin{array}{l}0 \\
25\end{array}$ & $\begin{array}{l}3 \\
5\end{array}$ \\
\hline
\end{tabular}

The profile of interviewees showed that there was no pattern with regard to qualifications, experience, training, employment tenure or salaries. The tenure of these Generation Xers showed that they generally stayed with an employer for short periods of time, which is consistent with the observation of Cordeniz (2002). Consequently, it is believed that the interviewees are not loyal to an employer, based on their history of general, short periods of time with their respective employers.

\section{Factors influencing the turnover intent of the Generation X public servants}

The participants were requested to respond to two questions regarding employee turnover. In the one instance they had to indicate what they believed were the reasons why others leave the organisation and then they were required to give reasons why they would leave. The eight interviewees gave at least 30 different reasons why employees would leave the employer. These reasons advanced for leaving the employer, whether in the case of the self or others, could be classified according to certain themes, presented in Table 2 below.

\section{Table 2: Themes for leaving the employer}

\begin{tabular}{|l|}
\hline Theme \\
\hline Remuneration \\
\hline Boss, whether unsupportive or having poor relations \\
\hline The job itself \\
\hline Career \\
\hline No growth, including lack of training \\
\hline Inflexibility \\
\hline Not taking individual needs into consideration \\
\hline Poor work environment \\
\hline
\end{tabular}

Source: Interview notes 
Table 2 warrants some elaboration. The themes indicating why the participants and "others" would leave the organisation are verbatim quotes. On closer scrutiny, as indicated in the next section, the reasons/themes advanced for leaving the organisation, whether in the case of others or self, are fairly similar and can be classified into the factors influencing turnover as proposed by Holtom et al. (2008) and the drivers of engagement as proposed by Cheese et al. (2008). It needs to be pointed out that the responses to the different questions seem brief and to the point. The interviewees all appeared to be withdrawn and hostile during the duration of the interviews. The weariness on the part of interviewees, sensed by the interviewer, can be clarified by earlier responses to the interview. The majority of interviewees indicated (Participants 1, 2, 7 and 8) or implied (Participants 3, 4, 5,6) that they were "not happy with their current job", which made them a turnover risk. In all cases the participants' unhappiness related to "poor salary" and "no growth opportunities" in some or other form. Salary forms part of reward systems, which is a contextual factor on the macro-level, according to Holtom et al. (2008), while it forms part of compensation in terms of the drivers of engagement as put forward by Cheese et al. (2008). In both instances salary is associated with recognition, which is important to Generation X employees (Cordeniz, 2002; Perrine, 2009; Pfau \& Kay, 2002; Rodriguez et al., 2003; Salopek, 2008). In this regard it is interesting to note that four of the participants (1, 2, 6 and 7) mentioned financial rewards directly as a reason why others would leave the organisation. In one instance (Participant 8) financial rewards were implied as part of the reasons for others to leave as this factor forms part of "better" offers and in another as "good job offers" (Participant 3 ) . Participants 3 and 8 mentioned earlier in the interview that the "basic salary of public servants should increase". Although these participants expressed their displeasure with their salaries in general, it is interesting that only Participants 3 and 8 mentioned an "increased" or "better" salary as a reason why they would leave their current employer. (The remainder masked their financial motivation by using poor pay as a reason why others would leave the organisation.)

Growth opportunities, in the context of the interviews, are interpreted to refer to the nature of the job, traditional and newer attitudes, and organisational context on both the macro- and micro- levels as per the Holtom et al. (2008) model. Growth opportunities can also be classified according to the drivers of engagement, as proposed by Cheese et al. (2008), namely, content, coping, community and career. Growth opportunities are also considered to be in line with Generation Xers' preference for challenging work as mentioned by Cordeniz (2002); Perrine (2009) Pfau and Kay (2002); Rodriguez et al. (2003) and Salopek (2008).

\section{DISCUSSION}

The profile of the interviewees suggests that they are indeed from Generation X. They are considered to be a turnover risk, especially in view of their current job dissatisfaction, whether explicitly mentioned or implied, in responses to the interview.

The brief overview of the profile of the interviewees suggests that they share the common characteristics of Generation Xers as put forward in the literature, as explained in a previous section. Thus one can expect that the turnover intentions of these Generation Xers would be inclined to be affected by the typical factors affecting turnover as suggested by Holtom et al. (2008) and engagement proposed by Cheese et al. (2008). This observation is supported by their response to the questions why they and others would leave the organisation.

In the case of Participant 1, in addition to remuneration, reasons advanced for others to leave included "inflexibility" and "not taking individual needs into consideration". In the context of this interview these reasons can be classified as the nature or the job, individual differences as well as organisational context on both the macro- and micro-levels, in terms of the Holtom et al. (2008) model. The applicable categories, according to the Cheese et al. (2008) drivers of engagement, include content and career. Earlier in the interview Participant 1 indicated that she "was not happy" with her job because it was "unchallenging and did not hold sufficient opportunities for me to develop". Another reason was given as "my supervisor's behaviour". Her responses are interpreted as referring to the nature of the job itself and organisational context on both the macro- and micro-levels (Holtom et al., 2008). This corresponds with what Cheese et al. (2000) say about job content. In particular, the job did not make physical or mental demands on her. Physical and mental demands are part of newer attitudes in the Holtom et al. (2008) model. Furthermore, according to her responses, the job did not give her a sense of achievement as it was unchallenging. These factors can also be classified into contextual factors at the macro- and micro-levels (Holtom et al., 2008) and coping as per the 
exposition of Cheese et al. (2008), as these are deemed to relate to work practices and support, especially by the line manager. Participant 1's response to why she would leave is deemed consistent with her reasons why others should leave as she specifically stated "an intolerable boss" and "unchallenging work".

Apart from remuneration, further reasons for others to leave advanced by Participant 2 included "no training" and "bad career management". No training was clarified as indicating a lack of growth, which is consistent with the nature of the job, attitudes and organisational context (Holtom et al., 2008) and coping, as put forward by Cheese et al. (2008). Bad career management is deemed to correspond to contextual factors at both the macro- and the micro-levels (Holtom et al., 2008) and career (Cheese et al., 2008), as she expressly stated during the interview that her job did not have "career advancement opportunities" and that her "current skills were not optimally utilised", which correspond to the views of Podsakoff et al. (2007). She indicated that she did not expect this situation to change in the future as she "experienced interpersonal difficulties with her supervisor, who is unsupportive" towards her. Furthermore, these responses are deemed to indicate a lack of recognition as the information communicated shows a feeling of under-appreciation. The reasons advanced why she (Participant 2) would leave, namely "no growth and no prospects for career advancement" are deemed to be congruent with the reasons why others would leave (except for remuneration). The interpersonal difficulties experienced with her supervisor can be categorised as organisational context on the microlevel (Holtom et al., 2008) and community (Cheese et al., 2008).

Participant 3 indicated that others would leave because of "good job offers", while he would leave for "promotion" and an "increase in salary". These reasons are deemed to be compatible and consistent with his earlier response where he indicated that his job "lacks a challenge" and correspond to the factors mentioned by Podsakoff et al. (2007). He also mentioned during the interview that "job security" was important to him. This response is not characteristic of Generation X. However, it is consistent with his job tenure - he had worked for only one previous employer, while he had been with the current employer for between five and six years. The factors influencing the perceived turnover of others, according to the Holtom et al. (2008) model, can be classified as the nature of the job, attitudes and organisational context on both the macro- and micro-levels. In the case of the Cheese et al. (2008) drivers of engagement, content, coping, compensation, community and career are applicable. The same categories are relevant in the case of the perceived factors why Participant 3 would leave.

The responses of Participant 4 regarding turnover, whether in the case of others or the self, are also deemed to be consistent. His reasons advanced for turnover, as in the case of the previous interviewees, related to the nature of the job (Holtom et al., 200) and content, as well as to coping according to Cheese et al. (2008) and challenge stressors as put forward by Podsakoff et al. (2007), which are consistent with newer attitudes in the Holtom et al. (2008) model. Lack of training and lack of support from management can be classified as organisational context on both the macro-and microlevels according to the Holtom et al. (2008) model and coping and community in terms of the drivers of engagement as put forward by Cheese et al. (2008). These reasons are congruent with his earlier response that his "job was unexciting and lacked developmental opportunities". However, he also mentioned that he "felt bad about his salary", which did not emerge in reasons for staff leaving the organisation.

"Not applying labour laws" and "unfair treatment", which relate to organisational justice, were the reasons advanced by Participant 5 . Organisational justice forms part of contextual factors at the microlevel in terms of the Holtom et al. (2008) model, while it is deemed to be part of both community (specifically a supportive environment) and compensation (in particular recognition) in the Cheese et al. (2008) model. This response of Participant 5 is consistent with his previous responses which include being "disillusioned with my salary" and "boring work content", and his need for "training to make the job more interesting". These descriptions of Participant's 5 work are deemed to be part of the nature of the job, and organisational context on the macro-level in terms of the Holtom et al. (2008) model, while content, coping and compensation relate to the drivers of engagement discussed by Cheese et al. (2008).

Only Participant 6 indicated that he did not want to leave at this stage, but he mentioned that others might leave because of low salaries and a poor working environment. Participant 6's responses are consistent with his earlier reactions in the interview relating to his work - i.e. he indicated that he required a "better working environment, including more challenges". Again the reasons maintained for 
employee turnover are consistent with the models of Holtom et al. (2008) and Cheese et al. (2008) as they pertain to the nature of the job, organisational context on both the macro- and micro-levels, attitudes (Holtom et al. 2008) and content, coping, compensation, community and career (Cheese et al. 2008) as explained previously.

Participants 7's response resonated to a greater or lesser degree with those of Participants 2, 3, 6 and 8 in terms of low salary and/or career advancement as expressed in promotion opportunities, while the reasons expressed for others to leave and his own reasons for leaving are considered to be consistent. As before, these reasons are consistent with both the models of Holtom et al. (2008) and Cheese et al. (2008). In particular, organisational context on both the macro- and micro-levels, of the Holtom et al. (2008) model and recognition, which is part of compensation, coping and community, of the Cheese et al. (2008) model are in agreement with the reasons advanced for staff turnover. These reasons are considered to be consistent with his prior responses in connection with his job, specifically his responses about his "poor salary" and his view that a "good working environment is required, with monthly meetings where staff can be supported to solve work-related problems".

In the case of Participant 8 it was alleged that others would leave for "better offers", while he would leave for a "better salary, new challenges, work related to my education" and because of "an unreasonable boss". As was explained previously, these reasons are congruent. Furthermore, they correspond to Participant's 8 responses such as "poor pay"; "unchallenging work content" and that he would leave his current position when he "finds work that is related to my education". Again these reasons are consistent with the models of Holtom et al. (2008) and Cheese et al. (2008). In particular, the nature of the job and organisational context on both the macro- and micro-levels are applicable in the case of the Holtom et al. (2008) model and content, coping and compensation in the instance of the Cheese et al. (2008) drivers of engagement.

In examining the above responses it seems as if all the reasons advanced for employees to leave the organisation correspond to those proposed by Holtom et al. (2008) and Cheese et al. (2008). The dominant reasons for leaving the organisation, irrespective of guise, were nature of the job (15), organisational context (15), attitudes (11) and individual differences (4) as per the Holtom et al. (2008) model, and coping (13), content (12), community (12), career (10) and compensation (9). The overriding themes were "poor salary" and "a lack of growth opportunities" which form part of nature of the job, attitudes, organisational context (Holtom et al. 2008) model and content, coping, community, compensation and career (Cheese et al. 2008) model. As mentioned earlier, the responses of the interviewees were consistent with the information provided during the interview and no new themes were introduced. Hence saturation occurred. The perceived turnover intent of Generation X public servants also resonated with those found by Salarzehi and Amiri (2010), Shahzad et al. (2011) and Singh and Loncar (2010) in the case of public servants. Furthermore, these reasons resonate with the characteristics of Generation X employees, especially recognition, including equitable pay, and challenging work. Consequently these participants are deemed to be turnover risks (except in the case of Participant 6 who indicated that he did not want to leave at that stage).

From these observations it is clear that the majority of participants were experiencing continuance or normative commitment rather than affective commitment. This is consistent with the information provided during the interview indicating that these participants were not engaged. As such it is not surprising that they were not affectively committed.

The reasons advanced for the turnover are consistent with those provided in the literature on turnover as well as with the characteristics of Generation Xers, which need to be present to facilitate affective commitment. The paramount role of the direct line manager was again established in these cases. It also emerged that employees experienced job dissatisfaction and consequently were not committed. The lack of commitment, in this case, can be ascribed to the lack of engagement.

\section{CONCLUSION}

The research on which this article is based set out to determine what factors influence the perceived turnover of Generation X public servants. Generation Xers are important to the organisation in creating and sustaining competitive advantage, as they are deemed to be the knowledge repositories of the organisation. Their unique characteristics, especially their nomadic behaviour, which is facilitated by employee mobility and competitors who are ready to poach talent, and their work ethic that is 
characterised by a decline in trust and loyalty to the organisation, make them a turnover risk, jeopardising the competitive sustainability of the organisation.

Merely keeping employees does not guarantee the competitive sustainability of organisations. Employees should experience and demonstrate affective commitment; that is, the employee identifies with the organisation, is involved in the organisation and is emotionally committed to the organisation. This means that the employees stay with the organisation because they want to be there. Affective commitment can only be achieved if the employee is engaged. An engaged employee knows what his/her organisation does to such a degree that he/she can articulate the competitive advantage with precision and passion, cares about customers and communicates with colleagues. In essence an engaged employee lives the strategy of the organisation and contributes in a meaningful way to performance (goal achievement). Engaged employees are recognised by their vigour, absorption and dedication.

The components of the turnover model proposed by Holtom et al. (2008) influence employee engagement and consequently commitment. The basic tenants of the Simon and March (1958) model (individual differences and nature of the job) remain the most prominent factors influencing employee turnover. Attitudes and contextual factors clarify turnover intent more comprehensively, as do withdrawal behaviours, which are displayed by employees with especially a continuance commitment.

The findings of this study show that the characteristics of the Generation X employees interviewed are consistent with those proposed in the literature. Furthermore, their turnover intent can be categorised according to the components of the model proposed by Holtom et al. (2008). The latent content of the interviews indicated that these interviewees were inclined to display continuance commitment and were not engaged at all. The drivers of engagement as discussed by Cheese et al. (2008) were all more or less absent, whether content (especially meaningful work that leads to development), coping (especially a supportive working environment), compensation (both financial rewards and recognition), community (in particular the lack of fulfilling and meaningful work that is enjoyable and a supportive environment), and congruence and career (chiefly work-life balance and autonomy to shape their career). As such these Generation Xers are deemed to be turnover risk, for some more immediate than others.

In this study, the paramount role of the line managers as proposed by Ahlrichs (2007); Cordeniz (2002); Dewhurst (2009), Dyer (2009), Graen et al. (1982), Johnson (2002); Kaiser and Hogan (2010); Perrine (2009); Pfau and Kay (2002); Rodriguez et al. (2003); Rose and Gordon (2010); Salopek (2008) and Wheeler et al.(2010), was again established. The line manager has control over all the components of the turnover model as proposed by Holtom et al. (2008), and as was demonstrated, engagement is omnipresent in these components. It is the role and responsibility of the line manager to facilitate engaged employees (which would equate to affective committed employees) by attending to these components. In so doing the line manager can prevent the costly implications of employee turnover while capitalising on their (continued) value to the organisation.

The research that is reported in this article set out to determine the perceived factors that influence the turnover intent of Generation X employees. It was established that the factors that influence the perceived turnover intent of Generation X public servants are congruent with those proposed by Holtom et al. (2008), in particular the nature of the job and contextual factors. These factors are consistent with the drivers of engagement proposed by Cheese et al. (2008), in particular coping, content, community, career and compensation. However, a question which arose is whether the turnover intent of Generation $X$ is any different from that of other generations. Consequently it is suggested that the turnover intent of different generations be investigated.

On the strength of the findings of this research it is concluded that, despite the obvious importance of employees to the organisation, it would seem that not all organisations succeed in giving their staff their most important asset - the attention they deserve. In view of the skills shortage and employee mobility this approach of organisations towards their staff may be detrimental to their long-term sustainability. 


\section{REFERENCES}

Ahlrichs, N. (2007). "Retaining four generations at work", TEC Australia \& New Zealand, September available at http://www.tec.com/au/node/215 accessed 30 October 2009.

Allen, N. \& Meyer, J.P. (1996). "Affective, continuance and normative commitment to organisations: An examination of construct validity", Journal of Vocational Behaviour, 49, 252-276.

Babbie, E. (2007). Practice of business and social research. Belmont, CA: Wadsworth.

Barney, J. \& Hesterly, W. (2011). Strategic Management and Competitive Advantage International Version, 4th Edition. Upper Saddle River: Pearson International.

Baruch, Y. \& Holtom B.C. (2009). "Survey response rate levels and trends in organizational research". Human Relations, 61 (8), pp 1139- 1160.

Berelson, B. (1952). Content Analysis in Communication Research. Glencoe, III: Free Press.

Bova, B., \& Kroth, M. (2001). "Workplace learning and Generation X", Journal of Workplace Learning, 13 (2), 57- 65.

Boxall, P. (1998). "Achieving competitive advantage through human resource strategy: towards a theory of industry dynamics", Human Resource Management Review, 8 (3), 265-288.

Cappelli, P. (2008). Talent on demand: Managing Talent in the Age of Uncertainty. Boston: Harvard Business Press.

Carpenter, M.A., \& Sanders, G. (2009). Strategic Management: A Dynamic Perspective. Upper Saddle River: Pearson International.

Cavanaugh, M.A., Boswell, W.R., Roehling, M.V. \& Boudreau, J.W. (2000). "An empirical examination of self-reported work stress among US managers", Journal of Applied Psychology, 85, 65-74.

Cheese, P., Thomas R.J. \& Craig, E. 2008. The talent powered organisation: Strategies for globalisation, talent management and high performance. London: Kogan Press Limited:

Collis, J., \& Hussey, R. (2009). Business research: a practical guide for undergraduate \& postgraduate students. 3rd ed. London: Palgrave Macmillan.

Colquitt, J.A., Conlon, D.E.., Wesson, M.J., Porter, C. \& Ng, K.Y. (2001). "Justice and the millennium: A meta-analytical review of 25 years of organisational justice research", Journal of Applied Psychology, 86: 425-445.

Cordeniz, J.A. (2002). "Recruitment, retention and management of Generation X: A focus on nursing professionals", Journal of Healthcare Management, 47 (4), 237-244.

Creswell, J.W. (2002). Educational research: Planning, conducting and evaluating quantitative and qualitative research. Upper Saddle River: Pearson Education in Onwuegbuzie, A.J. \& Leech, N.L. 2007. A call for qualitative power analysis. Quality and Quantity, 41: 105-121.

Creswell, J.W. (2009). Research design: qualitative, quantitative and mixed approaches. $3^{\text {rd }}$ ed. Thousand Oaks: Sage.

David F.R. (2011). Strategic Management: Concepts and Cases. $13^{\text {th }}$ ed. Upper Saddle River: Pearson International.

Demarco, D. (Undated). "7 strategies to retain Gen-X women", available at http://hr.blr.com/whitepapers.aspx?id=77349 accessed 30 October 2009. 
Dawley, D., Houghton, J.D. \& Buckley, N.S. (2010). "Perceived organisational support and Turnover intention: The mediating effects of personal sacrifice to job fit", Journal of Social Psychology, 150 (3): 238-257.

Dewhurst, S. (2009). "Does everyone understand what engagement means?", SCM, 13 (4): 14.

Dyer, K. (2009). "Taking employee engagement to new heights", SCM, 13 (4): 1.

Eisenhardt, K.M. (1989). "Building theories from case study research, Academy of Management Review, 14 (4): 532-550.

Fisher, C. (2010). Researching and writing a dissertation: An essential guide for business students. $3^{\text {rd }}$ ed. Essex: Pearson Education Ltd.

Frank, F.D., Finnegan, R.P. \& Taylor, C.R. (2004). The race for talent: retaining and engaging workers in the 21st century, Human Resource Planning, 27 (3): 12-25.

Fulford, M.D. (2005). That's not fair!: The test of a model of organisational justice, job satisfaction and organisational commitment among hotel employees. Journal of Human Resources in Hospitality \& Tourism, 4 (1):73-84.

Graen, G.B., Liden, R. \& Hoel, W. (1982). Role of leadership in the employee withdrawal process. Journal of Applied Psychology, 67: 868-872.

Grant, R.M. (2010). Contemporary strategy analysis. $7^{\text {th }}$ edition. London: Palgrave-McMillan.

Guest, G., Bunce, A. \& Johnson, L. (2006). "How many interviews are enough? An experiment with data saturation and variability", Field Methods, 18 (1): 59-82.

Habib, M.N., Mukhtar, S. \& Jamal, W. (2010). Why would I quit? Factors influencing Teachers' intentions to quit in private sector higher educational institutions of Peshawar, Pakistan. Interdisciplinary Journal of Contemporary Research in Business, 1 (12): 213-237.

Hallebone, E., \& Priest, J. (2009). Business and management research: paradigms \& practices. London: Palgrave Macmillan.

Harvey D. (2009). Talent strategy is vital, Personnel Today, June 23:13.

Haywood, L. (2011). Watch your workers win: Changing job demands and HRM Responses. Management Revue, 22 (1): 47-64.

Henning, E., Van Rensburg, W. \& Smit, B. (2004). Finding your way in qualitative research. Pretoria: Van Schaik.

Holbeche, L. (2009). Aligning human resources and business strategy, $2^{\text {nd }}$ ed. Oxford: Elsevier.

Holmes, S. (2009). "Methodological and ethical considerations in designing an Internet study of quality of life: A discussion paper". Nursing Studies, 2008, 46: 394 - 405.

Holtom, B.C., Mitchell, T.R., Lee, T.W. \& Eberly, M.B. (2008). Turnover and retention research: A Glance at the past, a closer review of the present and a venture into the future. Academy of Management Annals, 2 (1): 231-274. Available at http://0-

www.informaworld.com.Oasis.unisa.ac.za/smpp/section?content=a7949 accessed 7 April 2011.

Hom, P.W., Griffeth, R.W., \& Sellaro, C.L. (1985). Employee turnover. Cincinnati, OH: South Western College Publishing.

Iqbal, A. (2010). Employee turnover: Causes, consequences, and retention strategies in the Saudi organisations. The Business Review, Cambridge, 16 (2): 275-281. 
Jackson, S.E., Schwab, R.L. \& Schuler, R.S. (1986). Toward an understating of the burnout phenomenon. Journal of Applied Psychology, 71: 630-640.

Johnson, M. (2002). Talent magnet: getting talented people to work for you. London: Pearson Education.

Johnson, M. (2004). New rules of engagement: life-work balance and employee commitment. London: Chartered Institute of Personnel Development.

Kaiser, R.B. \& Hogan, R. (2010). How to (and how not to) assess the integrity of managers. Consulting Psychology Journal: Practice and Research, 62 (4): 216-234.

Kuean, W.L., Khin, E.W.S. \& Kaur, S. (2010). Employees' turnover intention to leave: The Malaysian context. The South East Asian Journal of Management. IV (2), October 2010.

Lee, T.R., Chen, S-Y., Wang, S-H., \& Dadura, A. (2010). The relationship between spiritual management and turnover intention. European Business Review, 22 (1): 102-116.

Lee, T.W. \& Mitchell, T.R. (1994). An alternative approach: The unfolding model of voluntary employee turnover. Academy of Management Review, 19: 51-89.

Lewis, R.E., \& Heckman, R.J. (2006). Talent management: a critical review, Human Resource Management Review, 16: 139-154.

Linne, L. (2009). Obtaining and retaining the best talent, Rough Notes, 152 (6): 32-34.

March, J.G. \& Simon, H.A. (1958). Organisations. New York: Wiley.

Maree, K. (ed). (2007). First steps in Research. Pretoria: van Schaicks.

Meyer, J.P., Stanley, D.J., Herscovitsch, L. \& Topolnytsky, L. (2002). Affective, continuance and normative commitment to the organisation: A meta-analysis of antecedents, correlates and consequences. Journal of Vocational Behaviour, 61: 20-52.

Morse, J.V. (1994). The dance of qualitative research designs: metaphor, methodology and meaning in Denzin, N.K., \& Lincoln, Y.S. 1994. Handbook of qualitative research. Thousand Oaks: Sage.

Myers, M. (2009). Qualitative research in business and management. Thousand Oaks: Sage.

Niewenhuizen, C. (2009). Scarcity, requirements and remuneration of applicants with management qualifications in the private-, public- and higher education sectors, Journal of Contemporary Management, 6: 310-234.

Olorunssola, E.O. (2010). Job satisfaction and gender factor of administrative staff in South West Nigeria. Contemporary issues in Education Research, 3 (10): 51-55.

Owen, R. (1813). An address to the superintendants of manufactories in Merrill, HF. (ed.). 1970. Classics in Management. American Management Association.

Pace, L.A. \& Livingston, M.M. (2005). "Protecting human subjects in Internet research". Electronic Journal of Business Ethics and Organization Studies, 10 (1): pp 35 - 40.

Pepe, M. (2010). The impact of extrinsic motivational dissatisfiers on employee level of job satisfaction and commitment resulting in intent to turnover. Journal of Business Economics and Research, 8 (9): 99-107.

Perrine, J.L. (2009). Recruitment and retention report: Strategies to boost RN retention, Nursing Management, 40 (4): 20-22.

Perry, C. (2001). Case research in marketing, The Marketing Review, 1: 303-323. 
Pfau, B.N., \& Kay, I.T. (2002). The human capital edge: 21 people management practices your company must implement (or avoid) to maximize shareholder value. New York: McGraw-Hill.

Pfeffer, J. \& Davis-Blake, D. (1992). Salary dispersion, location in the salary distribution and turnover among college administrators. Industrial \& Labor Relations Review, 45: 753-763.

Podsakoff, N.P., LePine, J.A. \& LePine, M.A. (2007). Differential challenge stressor-hindrance stressor relationships with job attitudes, turnover intentions, turnover and withdrawal behaviour: A metaanalysis. Journal of Applied Psychology, 92: 438-454.

Porter, L.W. \& Steers, R.M. (1973). Organizational, work and personal factors in employee turnover and absenteeism. Psychological Bulletin, 80: 151-176.

Prasad, B.D. (2008). Content analysis: A method din social science research in Lal Das, D.K and Bhaskaran, V (eds.). (2008) Research methods for Social Work, New Delhi: Rawat, pp.173-193.

Price, J.L. (1997). The study of turnover. Ames, IA, lowa State University Press.

Price, J.L. \& Mueller, C.W. (1981). A causal model of turnover for nurses. Academy of Management Journal, 24: 543-565.

Price, J.L. \& Mueller, C.W. (1986). Absenteeism and turnover of hospital employees. Greenwich, CT, JAI Press.

Rehka, S.K.R. \& Kamalanabhan, T.J. (2010). A three dimensional analysis of turnover intention among employees of ITEWS/BPO Sector. South Asian Journal of Management, 17 (3): 85-103.

Rodriguez, R.O., Green, M.T., \& Ree, M.J. (2003). Leading Generation X: Do the old rules apply?, Journal of Leadership and Organisational Studies, 9 (4): 67-75.

Rose, D.M \& Gordon, R. (2010). Retention practices for engineering and technical professionals in an Australian Public Agency, Australian Journal of Public Administration, 69 (3): 314-325.

Ruch, W. (2000). How to keep Gen X employees from becoming X-Employees, Training and Development, 54: 40-44.

Saunders, N.M.K., Lewis, P. \& Thornhill, A. (2009). Research methods for business students, $5^{\text {th }}$ ed. Essex: Pearson Education Ltd.

Salarzehi, H. \& Amiri, Y. 2010. A fuzzy and AHP approach for studying determinants of nurses' turnover (case study: State-owned hospitals in Shiraz, Iran). Interdisciplinary Journal of Contemporary Research in Business, 2 (7): 23-36.

Salopek, J.J. (2008). Retention buzz, Training and Development, January, 62 (1): 23-25.

SamGnanakkan, S. (2010). Mediating role of organisational commitment on HR practices and turnover intention among ICT professionals. Journal of Management Research, 10 (1): 39-61.

Schachter, D. (2009). Staff retention: Preparing for the recovery, Information Outlook, 13 (3): 36-37.

Schlesinger, L. \& Heskett, J. (1991). "Breaking the cycle of failure in services". Sloan Management Review, 32: 17-28.

Shahzad, K., Hussain, S., Bashir, S., Chishti, A.F. \& Nasir, Z.M. (2011). Organisazational environment, job satisfaction and career growth opportunities: A link to employee turnover intentions in public sector of Pakistan, Interdisciplinary Journal of Contemporary Research in Business, 2(9): 2011: 45-56. 
Singh, P. \& Loncar, N. (2010). Pay satisfaction, job satisfaction and turnover intent. Relations Industrielles, 65 (3): 470-490.

Soltani, E. \& Liao, Y.Y. (2009).Training interventions: fulfilling managerial ends or proliferating invaluable means for employees? European Business Review, 22 (2): 128-152.

Taylor, C.R. (2002). The talent focus, Training and Development, 56 (12): 26-31.

Tekleab, A.G., Takeuchi, R. \& Taylor, M.S. (2005). Extending the chain of relationships among organizational justice, social exchange and employee reactions: The role of violations. Academy of Management, 43: 146-157.

Temkin, S. (2008). Quarter of senior manager jobs held by blacks, Business Day, 2 December available at http://bis.hosted.inet.co.za/news accessed 30 October 2009.

Temkin, S. (2009). Firms put survival ahead of quotas, Business Day, 16 July 2009.

Vaughn, B. (2008). The top 10 incentives to recruit and retain Generation X employees available at http://diversitynetwork.dtui.com/members/dtui/blog/VIEW/ ... accessed 30 October 2009.

Western, J.W., \& Yamamura, J.H. (2006). Generational Preferences for work environment fit: effects on employee outcomes, Career Development International, 12 (2): 150-161.

Wheeler, A.R., Harris, K.J. \& Harvey, P. (2010). Moderating and mediating the HRM effectiveness intent to turnover relationship: The roles of supervisors and job embeddedness. Journal of Managerial Issues, 22 (2): 182-196.

Yin-Fah, B.C., Foon, Y.S., Chee-Leong, L. \& Osman, S. (2010). An exploratory study on turnover intent among private sector employees. International Journal of Business and Management, $\mathbf{5}$ (8): 57-64. 